\title{
Do Residential Water Demand Side Management Policies Measure Up? An Analysis of Eight California Water Agencies ${ }^{1}$
}

\author{
Mary E. Renwick and Richard D. Green ${ }^{2}$ \\ Water Resources Center, University of Minnesota, St. Paul, Minnesota 55108-6040
}

Received January 20, 1999; revised April 19, 1999

\begin{abstract}
To assess the potential of price and alternative demand side management (DSM) policies as an urban water resource management tool, an econometric model of residential demand is formulated and estimated. This econometric model incorporates alternative DSM policy instruments (such as water allocations, use restrictions, public education) and increasing block pricing schedules. The analysis relies on cross-sectional monthly time-series data for eight water agencies in California representing $24 \%$ of the state's population ( 7.1 million people). Results suggest that both price and alternative DSM policies were effective in reducing demand. However, the magnitude of the reduction in demand varied among policy instruments. (c) 2000 Academic Press
\end{abstract}

\section{INTRODUCTION}

Increased reliance on demand side management (DSM) policies as an urban water resource management tool has stimulated significant discussion among economists, water utility managers, and policymakers. While economists generally advocate residential water prices that reflect marginal costs as a means of reducing demand during periods of limited water supply availability, others argue that residential demand is price inelastic and thus price is a relatively ineffective DSM policy. This argument rests on both economic theory and empirical evidence that indicate residential water demand is expected to be relatively price inelastic. ${ }^{3,4}$ Yet, the argument that residential consumers do not respond to higher prices because demand is price inelastic is seriously flawed for at least two

${ }^{1}$ Funding for this research provided by California Department of Water Resources Contract B80705. Special thanks to Ray Hoagland, Steve Cowdin, and Marla Hambright for their valuable contributions to this work. Disclaimer: This report summarizes the results of price elasticity studies conducted by the Regents of the University of California for the California Department of Water Resources. Publication of any finding or recommendation in this report should not be construed as representing concurrence of the Department. Special thanks to the anonymous reviewers for their valuable comments and suggestions.

${ }^{2}$ Department of Agricultural and Resource Economics at University of California Davis. Comments can be directed to Mary E. Renwick, Water Resources Center, University of Minnesota, 146 Class Room Office Bldg., 1994 Buford Avenue, St. Paul, MN 55108-6040, or e-mail: renwi001@tc.umn.edu.

${ }^{3}$ Economic theory suggests that residential water demand should be price inelastic for three reasons: (1) there exist no close substitutes for water in most of its uses; (2) the amount of money spent on water is generally a relatively small share of the typical U.S. household budget; and (3) water is frequently demanded jointly with some other complementary good, as for bathing (Bach, 1980).

${ }^{4}$ Previous empirical studies indicating an own-price elasticity in absolute value of less than 1 include $[1,3,7,13,16,17]$. 
reasons. ${ }^{5}$ In addition, some advocates of non-price policy have argued that "the use of price as an allocation mechanism is constrained by the fact that water is generally regarded as a basic necessity, even a right, not an economic good" [2].

The problem facing water utility managers and policy makers is a lack of adequate information to determine the potential performance of price and alternative nonprice DSM policies in their communities. While water utility managers frequently adopt a combination of price and alternative DSM policy instruments, particularly during periods of limited supply availability, most previous economic analyses of residential water demand have ignored the effect of alternative DSM policies. ${ }^{6} \mathrm{Al}-$ ternative "non-price" DSM policy instruments-those that do not affect the price of water-include public education campaigns, rationing, water use restrictions, and subsidies for adoption of more water-efficient technologies. Failure to account for the influence of non-price DSM policies on demand when both price and non-price policies have been implemented may result in an overestimate of the price responsiveness of water demand.

To assess the potential of price and alternative DSM policy instruments to reduce demand, an econometric model of residential demand for water is formulated and estimated using a two-step estimation framework. This econometric model explicitly incorporates alternative non-price DSM policies, endogenous block pricing schedules, and a harmonic model to separately capture the effects of seasonality and climatic variability on demand, improving upon earlier specifications $[10,11,13]$. The analysis relies on agency-level cross-sectional monthly time-series data over an 8 -year period for eight urban communities in California, representing 7.1 million people.

\section{DSM POLICIES IN URBAN CALIFORNIA}

To assess the relative performance of price and alternative DSM policies to reduce aggregate demand, this research takes advantage of experience with residential DSM programs implemented in California during the 1989-1996 period. This period includes California's statewide drought, which persisted with varying degrees of intensity between 1985 and 1992, allowing examination of both price and alternative non-price policy instruments. Data collection efforts were conducted in eight urban water agency service areas covering $24 \%$ of California's population ( 7.1 million people). The eight agencies include the San Francisco Water District (SFWD), Marin Municipal Water District (MMWD), Contra Costa Water Agency (CCWA), East Bay Municipal Utility District (EBMUD), City of San Bernardino (SBERN), City of Santa Barbara (SBARB), Los Angeles Department of Water and Power (LADWP), and City of San Diego (SDIEGO). These areas were selected for a number of reasons, including varied hydrological conditions, geographical dispersion, and experience under different DSM policy regimes.

${ }^{5}$ First, since a market demand curve for most functional forms will be inelastic in some price ranges and elastic in others, reference to a demand curve as either inelastic or elastic must be made in relation to a specific range of prices. Second, some policymakers have erroneously equated price inelasticity with no price responsiveness. The description of residential demand as price inelastic is a technical definition; it simply means that a $1 \%$ increase in price results in a less than $1 \%$ decrease in consumption. In other words, consumers respond to higher prices, but at a rate less than proportionate to the price increase.

${ }^{6}$ Exceptions include $[16,17]$. 
Table I shows average single family monthly water use for the 1989-1996 period. There is significant variability in average water usage across agencies during the study period, ranging from approximately six hundred cubic feet (HCF) per month in San Francisco to approximately $25 \mathrm{HCF}$ per month in the city of San Bernardino (SBERN). This variability reflects, in part, such differences as average residential landscaped areas and climatic conditions. In San Francisco, most water use occurs indoors, as high-density housing limits potential landscaped area and concomitant irrigation. Average monthly water usage trended downward over the period for nearly all of the agencies. However, the reductions in use varied significantly between agencies on both an absolute and a relative basis. These reductions were particularly pronounced during the 1990-1992 period, presumably due to droughtinduced reductions in water supply availability and associated price and alternative non-price DSM programs.

Table II provides a summary of average marginal prices paid and type of pricing schedule in effect by agency. Average marginal water prices ranged from a low of $\$ 0.49$ per HCF in the City of San Bernardino (SBERN) to a high of $\$ 3.78$ per HCF in Marin Municipal Water District's (MMWD) service area. These differences reflect, in part, differences in water supply availability. For example, the city of San Bernardino lies at the foot of the mountains and has substantial groundwater reserves, while Marin Municipal Water District has coped with varying degrees of limited supply availability since the 1970s. Marginal prices trended upward over the 1989-1996 period; however, the magnitude of price increases varied by agency. Both uniform (UR) and increasing block (IB) rate schedules were observed across sample agencies and over time. Under uniform rates - the rate schedule most frequently employed-each household pays a fixed price per HCF. Under increasing block pricing schedules, the price per HCF depends on the total amount of water consumed. In general, marginal prices were higher in agencies where increasing block pricing schedules were in effect.

Beyond changes in residential prices, all of the agencies adopted at least one type of non-price DSM policy in an attempt to induce households to use water more efficiently. Table III provides a summary of key non-price DSM policies implemented by each agency during the 1989-1996 period. Due to the aggregate level of analysis,

TABLE I

Average Single Family Residential Monthly Water Use (in $\mathrm{HCF}^{a}$ ) by Agency: 1989-1996

\begin{tabular}{lrrrrrrrr}
\hline Year & SFWD & CCWA & SBARB & LADWP & MMWD & SBERN & SDIEGO & EBMUD \\
\hline \multicolumn{7}{c}{} & \multicolumn{7}{c}{ HCF $^{a}$} \\
1989 & 6.53 & 15.28 & 14.65 & 19.11 & 10.48 & 24.97 & 14.50 & 10.68 \\
1990 & 6.49 & 15.04 & 7.31 & 18.30 & 10.28 & 24.35 & 13.59 & 10.92 \\
1991 & 5.53 & 10.10 & 7.29 & 14.48 & 7.58 & 22.18 & 10.83 & 9.41 \\
1992 & 5.91 & 11.90 & 8.96 & 15.23 & 8.62 & 21.8 & 11.73 & 10.03 \\
1993 & 6.31 & 12.67 & 9.78 & 15.51 & 9.23 & 22.14 & 11.73 & 10.78 \\
1994 & 6.68 & 12.86 & 10.48 & 16.28 & 9.73 & 22.56 & 12.00 & 11.12 \\
1995 & 6.61 & 12.82 & 10.51 & 16.07 & 9.90 & 22.90 & 11.88 & 11.13 \\
1996 & 6.79 & 13.34 & 11.12 & 17.51 & 10.48 & 24.67 & 13.07 & 11.51 \\
$1989-1996$ & 6.36 & 13.00 & 10.01 & 16.56 & 9.54 & 23.20 & 12.42 & 10.70 \\
Avg & & & & & & & &
\end{tabular}

ane hundred cubic feet (HCF) equals 756 gallons. 


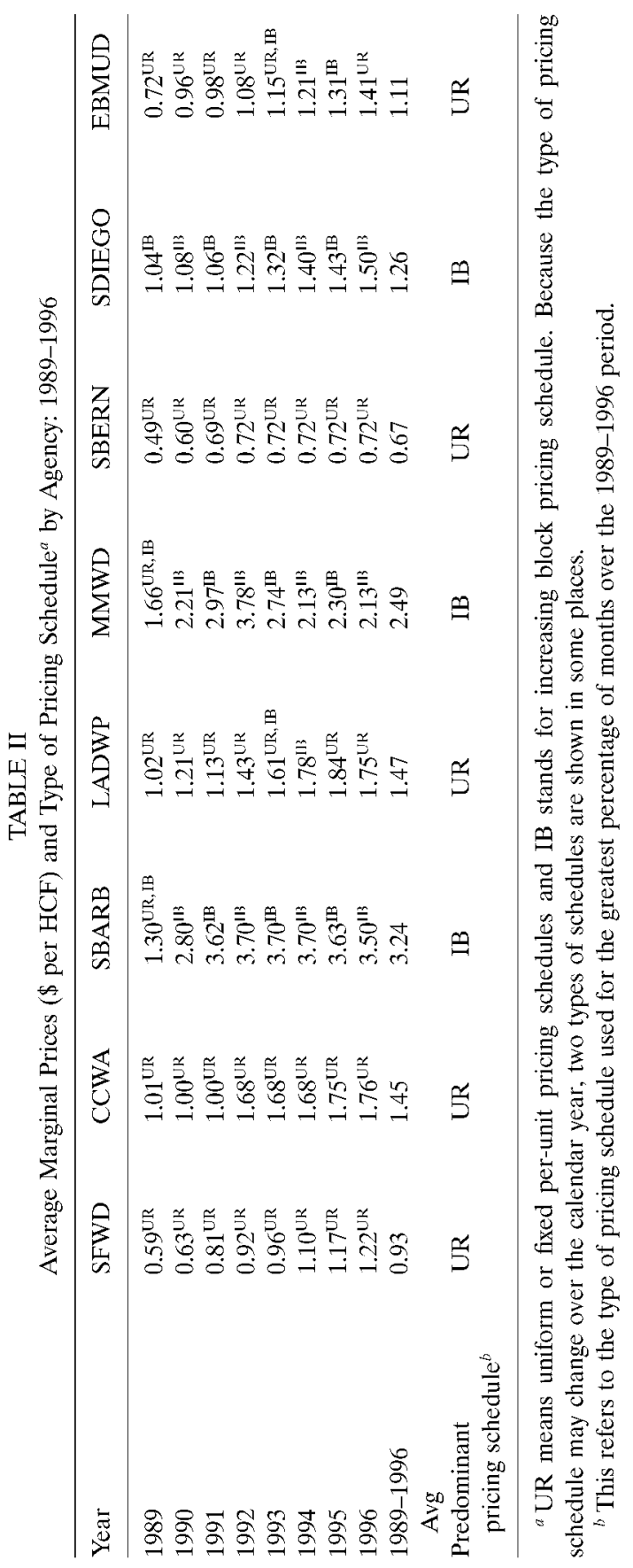


TABLE III

Overview of Key Non-price DSM Policy Instruments by Agency: 1989-1996

Type of DSM policy implemented ${ }^{a, b}$

\begin{tabular}{lcccccc}
\hline & \multicolumn{5}{c}{ Type of DSM policy implemented $^{a, b}$} \\
\cline { 2 - 7 } Agency & INFO & REBATE & RETRO & RATION & RESTRICT & COMPLY \\
\hline SFWD & $\mathrm{x}$ & $\mathrm{x}$ & & $\mathrm{x}$ & $\mathrm{x}$ \\
CCWD & $\mathrm{x}$ & $\mathrm{x}$ & $\mathrm{x}$ & $\mathrm{x}$ & $\mathrm{x}$ & \\
SBARB & $\mathrm{x}$ & $\mathrm{x}$ & $\mathrm{x}$ & $\mathrm{x}$ & \\
LADWP & $\mathrm{x}$ & $\mathrm{x}$ & $\mathrm{x}$ & & \\
MMWD & $\mathrm{x}$ & $\mathrm{x}$ & $\mathrm{x}$ & & \\
SBERN & & $\mathrm{x}$ & $\mathrm{x}$ & & \\
SDIEGO & $\mathrm{x}$ & $\mathrm{x}$ & $\mathrm{x}$ & & \\
EBMUD & $\mathrm{x}$ & $\mathrm{x}$ & $\mathrm{x}$ & & \\
\hline
\end{tabular}

Source. Agency-provided information.

"This does not represent an exhaustive list of DSM policies implemented. Rather, it identifies key policy instruments in effect during the 1989-1996 period.

${ }^{b}$ Policy definitions are as follows: public information campaigns (INFO), low-flow toilet rebate programs (REBATE), distribution of free plumbing retrofit kits (RETRO), water rationing/allocation policies (RATION), restrictions on certain types of water uses (RESTRICT), and San Francisco Water District's compliance affidavit policy (COMPLY).

only those policies expected to significantly influence demand are included in the table. DSM policies are aggregated into six basic types of policies [17]. The most popular types of non-price DSM policies implemented during the study period were voluntary measures, including public information campaigns (INFO) and subsidies to encourage adoption of more water-efficient technologies (RETRO, REBATE). Public information campaigns (INFO) alert households to shortages, attempt to motivate more water-efficient behavior, and provide information on means to reduce usage. Effective public information campaigns shift households' demand curves by altering tastes and preferences. Subsidies to encourage adoption of water-efficient technologies represent another means of shifting the household water demand curve by improving the technical efficiency of water-using fixtures. Subsidy programs represented include ultra-low-flow toilet rebate programs (REBATE) and distribution of free retrofit kits (RETRO). Retrofit kits usually include a low-flow showerhead, tank displacement devices, and dye tablets for leak detection.

The other types of DSM policies employed place direct controls on the level or nature of water use and are considered mandatory policy instruments. Rationing or allocation programs (RATION) generally allocate a fixed quantity of water to households, based on some allocation criteria, and impose penalties for exceeding the allotment, such as severe marginal price penalties. ${ }^{7}$ Water use restrictions (RESTRICT) constitute a more precise form of rationing. Use restrictions place constraints on when certain types of water use practices can occur, such as prohibitions on washing down sidewalks and driveways or bans on landscape irrigation during peak evapotranspiration hours. For example, the City of Santa Barbara banned nearly all forms of irrigation during the 1990-1991 period, except for drip and hand-held irrigation methods, and hired "water police" to enforce the policy. The San Francisco Water Department adopted a compliance affidavit (COMPLY) program. This program required all households to file an affidavit attesting that

${ }^{7}$ Strict rationing policies, where households are allowed a fixed quantity of water and then are cut off from service, are rarely observed for residential water usage due to sanitary and other considerations. 
specific water-efficient devices were installed in the household. No direct enforcement mechanisms were employed; however, households that did not file the affidavit faced higher marginal prices.

\section{A MODEL OF RESIDENTIAL DEMAND FOR WATER}

An econometric model of residential water demand is specified and estimated to identify the reduction in the aggregate quantity demanded attributable to price and alternative DSM policies. The model is composed of three basic components: price equations (two equations), climate equations (two equations), and a water demand equation. The price equations capture the influence of endogenous price effects on demand under block rate schedules since the marginal price depends on the quantity demanded. The climate equations capture the influence of variations in climate from "normal" seasonal patterns. ${ }^{8,9}$ Predicted values for the price and climatic variables are used in the second stage of the analysis to help explain changes in residential water demand and to assess the relative contributions of price and non-price policies in the reduction of demand.

The model of residential water demand takes the form

\section{Price Equations}

$$
\begin{aligned}
\ln \mathrm{MP}_{i t} & =\sum \alpha^{m p} \ln Z_{i t}^{m p}+e_{i t}^{m p}, \\
\ln D_{i t} & =\sum \alpha^{d w} \ln Z_{i t}^{d w}+e_{i t}^{m p},
\end{aligned}
$$

Climate Equations

$$
\begin{aligned}
& \ln \mathrm{DTEMP}_{i t}=\gamma_{0}^{t p}+\sum_{j=1}^{6}\left\{\gamma_{1, j}^{t p} \sin \left(\frac{2 \pi j t}{12}\right)+\gamma_{2, j}^{t p} \cos \left(\frac{2 \pi j t}{12}\right)\right\}+e_{i t}^{t p}, \\
& \ln \mathrm{DPREC}_{i t}=\gamma_{0}^{p r}+\sum_{j=1}^{6}\left\{\gamma_{1, j}^{p r} \sin \left(\frac{2 \pi j t}{12}\right)+\gamma_{2, j}^{p r} \cos \left(\frac{2 \pi j t}{12}\right)\right\}+e_{i t}^{p r},
\end{aligned}
$$

Water Demand Equation

$$
\begin{aligned}
\ln W_{i t}= & \beta_{0}+\beta_{1} \ln \widehat{\mathrm{MP}}_{i t}+\beta_{2} \ln \widehat{D}_{i t}+\beta_{3} \ln \mathrm{INC}_{i t}+\beta_{4} \mathrm{INFO}_{i t} \\
& +\beta_{5} \mathrm{RETRO}_{i t}+\beta_{6} \mathrm{REBATE}_{i t}+\beta_{7} \mathrm{RATION}_{i t}+\beta_{8} \mathrm{RESTRICT}_{i t} \\
& +\beta_{9} \mathrm{COMPLY}_{i t}+\beta_{10} \mathrm{LIRR}_{i t}+\beta_{11} \mathrm{HIRR}_{i t}+\beta_{12} \ln \widehat{\mathrm{TEMP}}_{i t} \\
& +\beta_{13} \ln \widehat{\mathrm{PREC}}_{i t}+\beta_{14} \mathrm{LOT}_{i t}+\beta_{15, j} \sin \left(\frac{\pi i j t}{6}\right) \\
& +\beta_{16, k} \cos \left(\frac{\pi i k t}{6}\right)+e_{i t}, \\
& j=1, \ldots, 5 ; \quad k=1, \ldots, 6 ; \quad t=1, \ldots, 96
\end{aligned}
$$

\footnotetext{
8"Normal" refers to the long-term seasonal average.
}

${ }^{9}$ Constant seasonal fluctuations in the climatic variables are filtered through a Fourier series of sine and cosine terms, as described below. 
where

$$
\begin{aligned}
& e_{i t}=\rho e_{i t-12}+u_{i t}, \\
& \ln Z_{i t}^{m p}=\left(\ln \mathrm{P} 1_{i t-1}, \ln \mathrm{P} 2_{i t-1}, \ln \mathrm{P} 3_{i t-1}, \ln \mathrm{INC}_{i t}, \ln \mathrm{HH}_{i t}, \ln \mathrm{LOT}_{i t}\right), \\
& \ln Z_{i t}^{d w}=\left(\ln \mathrm{P} 1_{i t-1}, \ln \mathrm{P} 2_{i t-1}, \ln \mathrm{P} 3_{i t-1}, \ln \mathrm{INC}_{i t}, \ln \mathrm{HH}_{i t}, \ln \mathrm{LOT}_{i t},\right. \\
&\left.\mathrm{BLOCK}_{i t}, \ln D_{i t-1}\right)
\end{aligned}
$$

$$
\begin{aligned}
& \ln \widehat{\mathrm{EMP}}_{i t}=\hat{e}_{i t}^{t p}=\ln \mathrm{DTEMP}_{i t}-\ln \mathrm{DTEMP}_{i t}, \\
& \ln \widehat{\mathrm{PREC}}_{i t}=\hat{e}_{i t}^{p r}=\ln \mathrm{DREC}_{i t}-\ln \mathrm{DPREC}_{i t} .
\end{aligned}
$$

Variable definitions are presented in Table IV and summary statistics for all variables are shown in Appendix Table A.I.

The marginal price and difference variable equations, $\ln \mathrm{MP}$ and $\ln D$, represent the first two of the five-equation demand system (Eqs. (1) and (2)). In the second stage of the analysis, the marginal price variable (MP) captures the effect of intramarginal price changes on demand, while the difference variable $(D)$ captures the effect of intermarginal rate schedule changes on water demand under increasing block price schedules, in accordance with the general "TaylorNordin" specification. ${ }^{10}$ However, to facilitate a more intuitive interpretation of the difference variable, $D$, under increasing block pricing schedules, we did a simple linear transformation of the traditional "Taylor-Nordin" by multiplying it by $-1 . .^{11}$

${ }^{10}$ Under block pricing schedules, the marginal price may convey only partial information. A simple example illustrates why this may be the case. Consider two households that demand the same amount of water and are identical in every other way, except that one faces an increasing block pricing schedule and the other faces a decreasing block pricing schedule. Although both households face the same marginal price, the total water bill and thus average price differ between the two households. As a result, the residual income available to each household after the water bill is paid differs. If this difference is large enough, otherwise identical households may behave differently.

${ }^{11}$ In the literature, the "Taylor-Nordin" difference variable, $D$, is generally defined as the total water bill minus what the bill would have been if all units were charged the marginal price. Fixed costs are ignored when the difference variable is calculated. Under a decreasing block pricing schedule the difference variable can be interpreted as an implicit income tax, while under an increasing block pricing schedule it can be interpreted as an implicit income subsidy. Using the standard definition of the difference variable ( $D$ equals the total bill minus what the bill would have been if all units were charged the marginal price), $D$ is always nonnegative under a decreasing block pricing schedule and always less than or equal to zero under an increasing block pricing schedule. Under this definition of $D$, the expected sign of the estimated coefficient is negative.

Traditional definition of $D=$ actual bill - bill if all units charged at the marginal price. More specifically, $D=\left(P_{1} Q_{1}+\left(\sum_{i=2}^{n} P_{i}\left(Q_{i}-Q_{i-1}\right)\right)\right)-P_{m} Q_{m}$. Our modified definition of $D=$ actual bill - bill if all units charged at the marginal price. More specifically, $D^{*}=-D=P_{m} Q_{m}-\left(P_{1} Q_{1}+\right.$ $\left.\left(\sum_{i=2}^{m} P_{i}\left(Q_{i}-Q_{i-1}\right)\right)\right)$. For decreasing block prices, the traditional construction of the difference variable provides an intuitive interpretation: an increase in the implicit income tax $(D)$ reduces water demand. For increasing block prices, this traditional definition provides little intuition; i.e., the expected sign of the coefficient is negative, implying that an increase in the implicit income subsidy ( $D$ more negative) increases water use. Using our modified definition, the difference variable is nonnegative under increasing block pricing schedules. This definition of the variable provides a more intuitive interpretation of the estimated coefficient under increasing block schedules. The anticipated sign of the estimated coefficient is positive, implying that an increase in the difference variable-the implicit income subsidy - is associated with higher household water use. 
TABLE IV

Variable Definition

\begin{tabular}{|c|c|c|}
\hline Indicator & Name/unit & Description \\
\hline$W_{i t}$ & Water use (HCF) & $\begin{array}{l}\text { Average SFR household monthly } \\
\text { water use }\end{array}$ \\
\hline $\mathrm{MP}_{i t}$ & Marginal price ( $\mathrm{S} \mathrm{HCF}$ ) & Marginal price of water \\
\hline$D_{i r}$ & Difference $(\$)$ & Difference variable ${ }^{a}$ \\
\hline $\mathrm{INFO}_{i t}$ & $\begin{array}{l}\text { Public information } \\
\text { dummy }\end{array}$ & $\begin{aligned} \mathrm{INFO}_{i} & =1 \text { for agency } i \text { and periods } t \\
& \text { when policy was in effect, } \\
& =0 \text { otherwise. }\end{aligned}$ \\
\hline $\mathrm{RETRO}_{i}$ & Retrofit kit dummy & $\begin{aligned} \operatorname{RETRO}_{i t} & =1 \text { for agency } i \text { and periods } t \\
& \text { when policy was in effect, } \\
= & 0 \text { otherwise. }\end{aligned}$ \\
\hline $\operatorname{REBATE}_{i t}$ & $\begin{array}{l}\text { Low-flow toilet rebate } \\
\text { dummy }\end{array}$ & $\begin{aligned} \operatorname{REBATE}_{i t} & =1 \text { for agency } i \text { and periods } t \\
& \text { when policy was in effect, } \\
& =0 \text { otherwise. }\end{aligned}$ \\
\hline RATION $_{i t}$ & Water rationing dummy & $\begin{aligned} \operatorname{RATION}_{i t} & =1 \text { for agency } i \text { and periods } t \\
& \text { when policy was in effect, } \\
& =0 \text { otherwise. }\end{aligned}$ \\
\hline RESTRICT $_{i}$ & $\begin{array}{l}\text { Water use restrictions } \\
\text { dummy }\end{array}$ & $\begin{aligned} \operatorname{RESTRICT}_{i t} & =1 \text { for agency } i \text { and periods } t \\
& \text { when policy was in effect, } \\
= & 0 \text { otherwise. }\end{aligned}$ \\
\hline COMPLY $_{i t}$ & Water affidavit dummy & $\begin{aligned} \text { COMPLY }_{i t} & =1 \text { for agency } i \text { and periods } \\
& t \text { when policy was in effect, } \\
= & 0 \text { otherwise. }\end{aligned}$ \\
\hline $\mathrm{LIRR}_{i}$ & $\begin{array}{l}\text { Limited outdoor water } \\
\text { use dummy }\end{array}$ & $\begin{aligned} \text { LIRR }_{i i} & =1 \text { for agency } i, \text { if expect low } \\
& \text { irrig/outdoor use, } \\
= & 0 \text { otherwise. }\end{aligned}$ \\
\hline $\mathrm{HIRR}_{i}$ & $\begin{array}{l}\text { High outdoor water use } \\
\text { dummy }\end{array}$ & $\begin{aligned} \text { HIRR }_{i t}= & 1 \text { for agency } i, \text { if expect high } \\
& \text { irrig/outdoor use, } \\
= & 0 \text { otherwise. }\end{aligned}$ \\
\hline $\mathrm{INC}_{i}$ & Income $(\$ 1000)$ & $\begin{array}{l}\text { Average monthly gross household } \\
\text { income }\end{array}$ \\
\hline $\mathrm{LOT}_{i}$ & Lot size $\left(1000 \mathrm{~s} \mathrm{ft}^{2}\right)$ & Average household lot size \\
\hline $\mathrm{BLOCK}_{i t}$ & Block pricing dummy & $\begin{aligned} \text { BLOCK }_{i t}=1 & \text { for agency } i \text { and periods } t \\
& \text { when block pricing schedule } \\
& \text { in effect, } \\
=0 & \text { otherwise. }\end{aligned}$ \\
\hline $\mathrm{DPREC}_{i t}$ & Precipitation & $\begin{array}{l}\text { Deviation of cum monthly rainfall } \\
\text { from historic mean }\end{array}$ \\
\hline DTEMP $_{i t}$ & Avg max air temp & $\begin{array}{l}\text { Deviation of avg max daily air } \\
\text { temp from historic mean }\end{array}$ \\
\hline $\cos \left(\lambda_{k} t\right)$ & Cosine harmonic & $\begin{array}{l}\lambda_{k}=2 \pi k ; k=1, \ldots, 6 \\
\text { (annual. . bimonthly harmonic) }\end{array}$ \\
\hline $\sin \left(\lambda_{k} t\right)$ & Sine harmonic & $\begin{array}{l}\lambda_{k}=2 \pi k ; k=1, \ldots, 6 \\
\text { (annual . . bimonthly harmonic) }\end{array}$ \\
\hline$P(X)_{i i}$ & $\begin{array}{l}\text { Marginal price } \\
\text { instruments }(\$)\end{array}$ & $\begin{array}{l}\text { Marginal price in block } X \text { of } \\
\text { agency is pricing schedule in } \\
\text { period } t \text {, where } X=1,2,3\end{array}$ \\
\hline
\end{tabular}

Note. $i=1, \ldots, 8$ agencies; $t=1, \ldots, 96$ months.

The difference variable $\left(D_{i t}\right)$ is defined as the difference between what a consumer would have paid if all units were purchased at the marginal price and the amount paid under the block pricing schedule. $D=P_{m} Q_{m}-m\left(P_{1} Q_{1}+\left(\sum_{i=2}^{m} P_{i}\left(Q_{i}-Q_{i-1}\right)\right)\right)$, where $m$ identifies the block in the price schedule in which consumption occurs, $P_{i}$ is the marginal price in the $i$ th block, $Q_{i}$ is the threshold quantity in the $i$ th block, and $Q_{m}$ is the total quantity demand and is contained in the $m$ th block. Time and agency subscripts are dropped here to reduce cumbersome notation. 
Following Nieswiadomy and Molina [13], the set of instrumental variables, $(\ln Z)$, includes the lagged marginal price for each block of the rate schedule and selected socioeconomic variables. ${ }^{12}$ Fitted values for the marginal price and difference variables are used in the second stage of analysis to help explain changes in residential water demand.

Equations (3) and (4) are used to capture and separately identify the effects of climate and seasonality on demand following Chesnutt and McSpadden [4]. The climatic variables include maximum daily air temperature (DTEMP) and cumulative monthly precipitation (DPREC). Both variables are expressed in deviation form from their 30 -year historical mean. ${ }^{13}$ Climate variables are highly correlated with seasonality because temperature is high in the summer and low in the winter. Likewise, rainfall is higher in winter than in summer. To mitigate the effects of multicollinearity, we define the climatic variables, temperature and rainfall, so that the influence of seasonal patterns is removed. This is achieved by regressing temperature and rainfall on the seasonal harmonics (sine and cosine terms) and then using the residuals from these regressions to capture the effects of climatic components in the demand equation in the second stage of analysis. Thus, the climatic variables represent only the effect of deviations of climate from normal patterns in the demand equation; that is, the seasonal components have been removed from the climatic variables by construction.

Following Lyman [9], Chesnutt and McSpadden [4], and others, the water demand equation (Eq. (5)) is specified as a logarithmic functional form. The demand equation includes both the fitted marginal price $(\ln \widehat{\mathrm{MP}})$ and difference $(\ln \widehat{D})$ variables. Under increasing block pricing schedules, the difference variable, as defined in this paper, acts as an implicit income subsidy and is expected to be positively correlated with water use. The linear transformation of the difference variable simply facilitates a more intuitive interpretation of the estimated coefficient and leaves the remaining estimated coefficients unchanged.

Alternative non-price DSM policies are also expected to influence water demand. Dummy variables representing the six types of DSM policies implemented-as described in Table III-are included in the demand equation and are expected to negatively correlate with water use. These dummy variables include public information campaigns (INFO), distribution of free retrofit kits (RETRO), low-flow toilet rebate programs (REBATE), water rationing policies (RATION), water use restrictions (RESTRICT), and San Francisco's compliance affidavit policy (COMPLY).

Household characteristics are also expected to influence demand. Median household income (ln INC) for each agency's service area is included in the model and expected to be positively correlated with demand. A variable measuring lot size $(\ln$ LOT) is also included in the demand equation. Households with larger lots are expected to be positively correlated with discretionary outdoor water usage, all other factors held constant.

\footnotetext{
${ }^{12}$ We followed Nieswiadomy and Molina [13] in the selection of the set of instrumental variables, including marginal prices in each block together with all the socioeconomic explanatory variables. The price instruments, $\ln P X_{i i}$, are lagged one period to avoid contemporaneous correlation with water use under block pricing. Climatic and policy dummy variables were not included.

${ }^{13}$ The historical mean is the long-term average based on up to 30 years of climatic data for each weather station.
} 
In addition, fixed-effects irrigation dummy variables, representing low (LIRR), medium (MIRR), and high (HIRR) outdoor water use, are incorporated into the demand equation. These variables accounted for expected differences in outdoor water use. Although larger lots tend to be positively correlated with higher water usage due to landscape irrigation demands, departures from this pattern exist. For example, the average lot in Municipal Water District's service area is relatively large; however, most households maintain native landscape with very limited or no irrigation requirements. In contrast, while average lots in the LADWP service area are moderately sized, outdoor water usage is expected to be higher due to the preponderance of swimming pools and other outdoor water-using activities. These fixed-effect dummy variables were selected, in lieu of agency-specific dummies, to prevent the model from becoming too complex given that estimation issues associated with collinearity among explanatory and agency-specific dummy variables existed. The MIRR variable was dropped to prevent the "dummy variable trap" and, thus, is included in the intercept term. The estimated coefficients on remaining outdoor water use dummy variables act as an intercept shifter. Thus, the signs on the estimated low (LIRR) and high (HIRR) outdoor water use dummy variables are negative and positive, respectively.

Seasonality in residential water demand is captured through a harmonic model consisting of a Fourier series of sine and cosine terms of various harmonic frequencies where $j$ represents the frequency of each harmonic. Equivalently, one can capture the seasonality effects by using 11 monthly dummy variables. Note that the terms $\sin (\lambda 6 t)=\sin (2 \pi 6 / 12) t=\sin (\pi t)=0$ for $t=1,2, \ldots T{ }^{14}$ Thus, there are only five sine terms but six cosine terms. In addition, because the lower frequencies tend to explain most of the seasonal fluctuations, the higher frequencies can be omitted with little predictive loss [4]. However, rather than truncate the Fourier series a priori, all six harmonics are initially included and then those which do not contribute "sufficiently" to the explanatory power of the model are removed [5]. ${ }^{15}$

To capture the influence of changes in historical climatic patterns, fitted residuals from the first-stage air temperature $\left(\ln \widehat{T E M P}_{i t}\right)$ and precipitation $\left(\ln \widehat{P R E C}_{i t}\right)$ equations (Eqs. (3) and (4)) are included in the demand equation. These variables capture the effects of climate, temperature, and rainfall, departing from its normal seasonal pattern. Air temperature is expected to be positively correlated with water demand, while the precipitation is expected to be negatively correlated with water demand.

As detailed above, water demand (Eq. (5)) is estimated using a generalized leastsquares approach. An instrumental variable approach is used to estimate price and climatic equations (Eqs. (1)-(4)) to purge (asymptotically) the correlation between price variables and error terms under increasing block pricing schedules. The water demand equation was transformed to correct for a 12th-order autoregressive

\footnotetext{
${ }^{14} \lambda=(2 \pi / m)$, where $m$ equals the number of observations per year. For example, $m=12$ for monthly observations and $m=4$ for quarterly observations.

${ }^{15}$ The use of a Fourier series to represent seasonality in a regression model dates back to Hannan [6]. For an excellent introductory discussion of Fourier series, see Protter and Morrey [15]. For a more detailed treatment of using a Fourier series in a regression context, see Doran and Quilkey [5].
} 
disturbance process, $\mathrm{AR}(12)$, and expected groupwise heteroscedasticity (due to anticipated differences in water use variability between agencies), care being taken to distinguish between the cross-sectional and time-series observations. ${ }^{16,17}$ The resulting generalized least-squares approach yields consistent estimators. Given that the initial observations are dropped, the estimators are equivalent to conditional maximum likelihood estimators.

\section{DATA}

Agency-level mean monthly single family water use and cost data were obtained from each agency for the 8-year (1989-1996) period. ${ }^{18}$ Information relating to alternative non-price DSM policies was collected. Socioeconomic data such as median household income and number of people per household were estimated from the 1990 U.S. Bureau of the Census Population and Housing Summary. These estimates were based on aggregation of census tracts within each agency's service area. ${ }^{19}$ In addition, average lot sizes for each agency were estimated using the U.S. Census Topographically Integrated Geographic Encoding and Referencing system (TIGER), the Sacramento Area Council of Governments' 1990 Census Geographic Areas Reference List, and agency-provided maps. ${ }^{20}$

Cumulative monthly precipitation and average monthly maximum daily air temperature data were compiled based on actual daily observations by the Western Regional Climate Center in Reno, Nevada. These compilations included both monthly data for the 1989-1996 period and the long-term historical data. For each agency,

${ }^{16}$ In the estimation procedure a consistent estimate of $\rho$ is first obtained and then used to transform the series. The model is reestimated under the assumption of groupwise heteroscedasticity to obtain consistent estimates.

${ }^{17}$ Durbin-Watson statistics were estimated to test for the possibility of 1st- and 12th-order, AR(1) and $A R(12)$, autoregressive processes. The null hypotheses of no $A R(1)$ and $A R(12)$ were rejected at the 0.01 significance level. Following Wallis [19], a joint test for $\operatorname{AR}(1)$ and $\operatorname{AR}(12)$ was estimated. The likelihood ratio test of joint AR(1) and AR(12) processes was rejected at the 0.01 significance level. An AR(12) process was selected given monthly annual data.

${ }^{18}$ Bimonthly data were converted to monthly data where necessary.

${ }^{19}$ The 1990 U.S. Census median gross income data are adjusted annually with an income index based on county-level data for California.

${ }^{20}$ Averages for each agency were calculated based on total land in the service area less easily identifiable nonresidential lands divided by number of housing units. Given the lack of available information on average single family lot size in each agency's service, the following methodology was used to provide proxy estimates of average lot sizes. First, agency service land areas and the concomitant total number of housing units, including multiple dwelling units, were identified using 1990 Census data and agency-provided information. Agency service areas were superimposed on 1990 digitized U.S. Census maps using the Topographically Integrated Geographic Encoding and Referencing system (TIGER) and Part B of the 1990 Census Geographical Areas Reference List published by the Sacramento Area Council of Governments Regional Data Center. Second, American Automobile Association maps were used to identify large parks, green spaces, and obvious industrial and commercial areas. In addition, a census tract grid search methodology was employed to identify other significant nonresidential areas. For example, in San Francisco any quarter-square-mile area (160 acres) with a population density of less than 250 people was examined. For all agency service areas, the estimated total residential agency service area was calculated as the total land area less area identified as nonresidential. The estimated total number of housing units equals the number of units in the area less any housing units in identified "nonresidential," according to the 1990 Census figures. Thus, average lot size equals adjusted total land area divided by adjusted number of housing units. 
a pooled measurement for each climatic variable was constructed based on actual measures from weather stations in each area. ${ }^{21}$ The pooled approach for climatic variables was selected to increase measurement precision, given potential variability in the quality and availability of climatic variables across each agency's service area.

\section{RESULTS}

The estimation results for the water demand equation, shown in Table $\mathrm{V}$, indicate good model performance. ${ }^{22}$ All coefficients generally exhibit expected signs and are statistically significant. The results appear robust to changes in specification (see Appendix Table A.V). The adjusted $R^{2}$ for the water demand equation is 0.91 .

The signs and statistical significance of the climatic, socioeconomic, and structural variables also demonstrate the model's robust performance when the specification is changed (see Appendix Table A.V). The estimated coefficient on the income variable (ln INC) and predicted increasing block price implicit income subsidy variable $(\ln \hat{D})$ - known as the difference variable-exhibit the anticipated positive effect of household water use. The magnitude of the income variable implies that a $10 \%$ increase in income will increase average household monthly water demand by $2.5 \%$. This income elasticity of demand is comparable with other residential water demand studies $[7,8,11] .^{23}$ The difference variable is statistically insignificant, likely due to the aggregated nature of the water use and billing data and associated reduction in variability.

The estimated coefficient on the lot size (1n LOT) variable, a proxy for landscaped area, is positive and statistically significant. The larger the landscaped area, the greater the demand for water. The magnitude of the estimated coefficient implies that a $10 \%$ increase in lot size square footage will result in a $2.7 \%$ increase in water demand on average, all other factors held constant. The statistically significant estimated coefficients on the outdoor water use dummy variables, LIRR and HIRR, possess the anticipated negative and positive signs, respectively. Water demand is lower in areas with limited outdoor water (due to such factors as conversion to native drought-tolerant landscaping) and higher in areas with more outdoor water use (due to a greater prevalence of water-intensive landscaping, swimming pools, and fountains).

The estimated coefficient on the deseasonalized maximum air temperature variable is positive and statistically significant, suggesting that higher than average maximum daily air temperatures observed during the period increase the demand for water. The rainfall variable captures the effect of deviations in rainfall during the period 1989-1996 from 30-year historical averages. The estimated coefficient of the

${ }^{21}$ The weather stations for each agency are shown in Appendix Table A.II.

${ }^{22}$ Estimation results for the stage 1 price and climatic variables are shown in Appendix Table A.III. The adjusted $R^{2}$ for the first-stage estimations of the marginal price and difference variables are 0.91 and 0.85 , respectively. High $R^{2}$ in the first stage are essential in order to achieve good instruments.

${ }^{23}$ Howe and Linaweaver [7] estimated the income elasticity of demand as 0.32 for domestic water uses and 0.66 for irrigation demand. The estimated income elasticities of demand calculated by Jones and Morris [8] for their three marginal price models ranged from 0.40 to 0.55 . In the three marginal price models estimated by Nieswiadomy [11], he found the income elasticity of demand to range from 0.28 to 0.44 . 
TABLE V

Water Demand Estimation Results

\begin{tabular}{|c|c|c|c|}
\hline Variable & Est coefficient & Variable & Est coefficient \\
\hline Intercept & $\begin{array}{l}2.61 \\
0.16^{* * * *}\end{array}$ & $\ln I N C$ & $\begin{array}{l}0.25 \\
0.10^{\text {** }}\end{array}$ \\
\hline $\ln \hat{M} P$ & $\begin{array}{c}-0.16 \\
0.03^{\text {*** }}\end{array}$ & $\ln L O T$ & $\begin{array}{l}0.27 \\
0.03^{* * *}\end{array}$ \\
\hline $\ln \hat{D}$ & $\begin{array}{l}0.01 \\
0.02\end{array}$ & $H I R R$ & $\begin{array}{l}0.53 \\
0.05^{\text {*ै* }}\end{array}$ \\
\hline$I N F O$ & $\begin{array}{c}-0.08^{* * *} \\
0.02\end{array}$ & LIRR & $\begin{array}{l}-0.30 \\
0.04^{\text {* }} \text { * }\end{array}$ \\
\hline$R E B A T E$ & $\begin{array}{c}-0.004 \\
0.02\end{array}$ & $\ln T E \hat{E M P}$ & $\begin{array}{l}0.45 \\
0.11^{\text {w }}\end{array}$ \\
\hline RETRO & $\begin{array}{l}-0.09 \\
0.02^{* * * *}\end{array}$ & $\ln P \hat{R E C}$ & $\begin{array}{r}-0.01 \\
0.01\end{array}$ \\
\hline RATION & $\begin{array}{c}-0.21 \\
0.03^{* * *}\end{array}$ & SIN1 & $\begin{array}{c}-0.28 \\
0.02\end{array}$ \\
\hline RESTRICT & $\begin{array}{l}-0.34 \\
0.04^{* * *}\end{array}$ & COS1 & $\begin{array}{l}0.10 \\
0.02\end{array}$ \\
\hline \multirow[t]{2}{*}{ COMPLY } & $\begin{array}{l}0.003 \\
0.03\end{array}$ & RHO & $\begin{array}{l}0.58 \\
0.03^{\text {***}}\end{array}$ \\
\hline & & $R^{2}(\operatorname{Adj})$ & 0.91 \\
\hline
\end{tabular}

* Significant at the 0.10 level.

** Significant at the 0.05 level.

$* *$ Significant at the 0.01 level.

deseasonalized rainfall variable was statistically insignificant. Given the very low levels of cumulative monthly rainfall in the agency service areas, both during the period 1989-1996 and historically, the magnitude of the deviation was minimal-9/100 of an inch on average (see Appendix Table A.I). These results suggest that deviation in rainfall from historical patterns observed during the period of analysis appear to be insignificant in comparison to seasonal effects.

As described above, seasonality is captured in the model through a Fourier series of sine and cosine terms of various harmonic frequencies. The estimated coefficients on the annual frequency sine and cosine terms were statistically significant. Higher frequency terms were dropped from the final specification due to the minimal loss in explanatory power associated with their omission, following Doran and Quilkey [5]. ${ }^{24}$ These results provide support for Chesnutt and McSpadden's [4] argument that "because the lower frequencies tend to explain more of the seasonal fluctuation, the higher frequencies can be omitted with little predictive loss."

The coefficient on the marginal price of water ( $\ln \widehat{\mathrm{MP}})$ is, as expected, negative and statistically significant, as shown in Table V. The estimated own-price elasticity of demand equals -0.16 , implying that a $10 \%$ increase in price will reduce the

\footnotetext{
${ }^{24} \mathrm{~A}$ likelihood ratio test was performed to test the null hypothesis that the coefficients on higherorder sine and cosine terms were equal to zero and was not rejected at the .01 significance level. More specifically, $-2\left(\ln L_{R}-\ln L_{U}\right)=-2(428.55-431.11)=5.12$, which is $\chi^{2}$ distributed with 9 degrees of freedom.
} 
aggregate quantity demanded by $1.6 \%$. Isolating seasonal own-price elasticities indicated that the own-price elasticity of demand for the summer months (June-August) equals $-0.20 .^{25}$ These own-price elasticity estimates are within the order of magnitude of previous studies. These estimates range from -0.15 to $-0.52[1,3,10-12]$. The estimated own-price elasticities are slightly less than those previously estimated for urban areas in California, which range from -0.22 to $-0.37[2,16,17]$, perhaps due to the exclusion of alternative DSM policy variables [2] and the significantly larger range of marginal prices $[16,17]$ in these other studies. In interpreting these estimation results, particularly for policy purposes, it is important to remember that the estimated own-price elasticities are more reliable within the region of observed marginal prices, which ranged from $\$ 0.47$ to $\$ 4.25$.

Estimation results also indicate that alternative DSM policy instruments had a measurable effect on aggregate water demand. The estimated coefficients on the public information campaigns (INFO), retrofit subsidies (RETRO), water rationing (RATION), and water use restrictions (RESTRICT) policy dummies were all negative and statistically significant. The magnitudes of the coefficients on the public information campaign policy (INFO) and retrofit subsidies (RETRO) variables imply that implementation of these policies reduced average household water demand by approximately $0.9 \mathrm{HCF}(8 \%)$ and $1 \mathrm{HCF}(9 \%)$, respectively. ${ }^{26}$ The magnitudes of the coefficients on the water rationing (RATION) and use restrictions (RESTRICT) variables suggest these policies reduced average household water demand by $2.1 \mathrm{HCF}(19 \%)$ and $3.3 \mathrm{HCF}$ (29\%), respectively. These results suggest that more stringent mandatory policies, such as use restrictions, reduced demand substantially more than voluntary measures, such as public information campaigns. While these results provide further empirical evidence regarding the effectiveness of alternative DSM policy instruments, they must be interpreted with caution due to the aggregate nature of the data and definition of policy instruments.

The remaining two DSM policy dummies (REBATE and COMPLY) were not statistically significant, probably as a result of aggregation of the policies across several agencies and definition of when the policy was in effect. ${ }^{27}$ These results do not imply that these latter two types of policies (REBATE and COMPLY) are ineffective DSM instruments; rather, they imply that they did not have a measurable influence on demand in this study. They do suggest, however, that the definition of policy variables may be extremely important for accurate measurement since the nature of these types of policy instruments may vary either over time or cross-sectionally.

\section{CONCLUSIONS}

The goal of this research was to assess the relative performance of alternative DSM policy instruments in reducing aggregate demand. Results indicate that DSM

\footnotetext{
${ }^{25}$ Estimated by interacting a summer seasonal dummy variable with the marginal price variable using an equivalent model containing monthly dummy variables instead of the Fourier series to capture seasonality. The estimated coefficient on the interactive marginal price variable was -0.038 , resulting in an estimated own-price elasticity of -0.198 for the summer months.

${ }^{26}$ Based on estimated coefficients in Table $\mathrm{V}$ and mean monthly water use of $11.25 \mathrm{HCF}$.

${ }^{27}$ The definition of when a policy went into effect and for how long can be a difficult issue from a modeling perspective. For example, many agencies had low-flow toilet rebate programs for years with significantly varying degrees of emphasis placed on the program. Similarly, the San Francisco Water District's compliance affidavit policy (COMPLY) was in effect for over a year before the majority of households filed their affidavits.
} 
policies were effective in reducing demand. However, the magnitude of the reduction in demand varied significantly. These results highlight the importance of accounting for the influence of alternative DSM policies in analyses of residential water demand.

Aggregate single family household demand was responsive to price changes. However, price responsiveness varied seasonally. In particular, aggregate demand was $25 \%$ more price responsive in the summer months, reflecting the more discretionary nature of outdoor water use. These results suggest that price policy will achieve a larger reduction in demand during summer months or in communities with larger irrigated landscaped areas, all other factors held constant.

Results indicate that alternative non-price DSM policies reduce aggregate water demand. However, the characteristics of the instrument influence the outcome of these policies. More stringent mandatory policies, such as use restrictions and water allocations, reduced aggregate demand more than voluntary measures, such as public information campaigns and retrofit subsidies.

What are the implications of this research for urban water policy makers? A key policy implication of these results is that policymakers can choose from a menu of policy options, which includes price and alternative non-price DSM instruments, to reduce aggregate water demand. In general, relatively moderate (5-15\%) reductions in aggregate demand can be achieved through modest price increases and "voluntary" alternative DSM policy instruments, such as public information campaigns. However, to achieve larger reductions in demand (greater than 15\%), policymakers will likely need to consider either relatively large price increases, more stringent mandatory policy instruments (such as use restrictions), or a package of policy instruments.

In addition, policymakers need to be aware that socioeconomic and structural characteristics of households in the community are expected to influence policy responsiveness. Price responsiveness is expected to vary based on household income. Lower income households are expected to be more price responsive than wealthier households because their water bill typically constitutes a larger share of the household budget. Thus, price policy may achieve a larger reduction in aggregate demand in lower income communities than in higher income communities, all other factors held constant. In contrast, landscape use restrictions will reduce aggregate demand among households with larger landscaped areas, which tend to be higher income. Landscape use restrictions are expected to reduce demand more in suburban communities, where households maintain larger amounts of landscaping, than in higher density urban areas.

Further research on residential water demand is needed to address two important issues. First, more information is needed on how household characteristics influence policy responsiveness. Since water is a highly political good, the equity implications of alternative policy decisions are an important ingredient in the policy formulation process. Armed with this information, regional urban water policy planners can design a DSM program which achieves the required reduction in demand as efficiently as possible, given equity considerations. Second, since policy makers frequently adopt more than one policy during a water shortage, more research is needed to understand how the interaction of policy incentives influences the overall reduction in aggregate demand. 


\section{APPENDIX}

APPENDIX TABLE A.I

Mean and Standard Deviation for Variables

\begin{tabular}{llrc}
\hline $\begin{array}{l}\text { Variable } \\
\text { indicator }\end{array}$ & \multicolumn{1}{c}{ Name/unit } & Mean & $\begin{array}{c}\text { Standard } \\
\text { deviation }\end{array}$ \\
\hline$W_{i t}$ & Water use (HCF) & 12.71 & 6.25 \\
MP $_{i t}$ & Marginal price (\$HCF) & 1.57 & 0.93 \\
$D_{i t}$ & Difference (\$) & 1.16 & 2.50 \\
$\mathrm{INC}_{i}$ & Income (\$) & 36,575 & 7,413 \\
LOT $_{i}$ & Lot size (ft & \\
PREC $_{i t}$ ) & Cum monthly precipitation (inches) & 2,576 & 1,015 \\
PRECLT $_{i t}$ & Long-term avg cum monthly precipitation (inches) & 1.77 & 3.04 \\
DPREC $_{i t}$ & Dev of Cum monthly prec. from $L-T$ avg (inches) & 1.68 & 1.81 \\
TEMP $_{i t}$ & Avg max monthly air temp (degrees Fahrenheit) & 0.09 & 2.39 \\
TEMPTL $_{i t}$ & Long-term avg max air temp (degrees Fahrenheit) & 71.3 & 9.1 \\
DTEMP $_{i t}$ & Dev of avg max air temp from $L-T$ avg (degrees Fahrenheit) & 71.0 & 8.9 \\
\end{tabular}

Number of observations: 776 .

APPENDIX TABLE A.II

Weather Stations by Agency

\begin{tabular}{ll}
\hline \multicolumn{1}{c}{ Agency } & \multicolumn{1}{c}{ Weather station } \\
\hline San Bernardino & San Bernardino \\
& Little Creek FTHL Blvd \\
Los Angeles Dept. of Water and Power & Los Angeles Civic Center \\
& San Pedro \\
& Los Angeles Airport \\
& UCLA \\
& Canoga Park/Pierce College \\
& Culver City \\
Santa Barbara & Santa Barbara \\
San Francisco Water District & San Francisco Richmond \\
& San Francisco Mission Dolores \\
Marin Municipal Water District & Kentfield \\
& San Rafael Civic Center \\
Contra Costa Water Agency & Concord Wastewater \\
& Martinez 25 \\
East Bay Municipal Water District & Richmond \\
& Berkeley \\
& Oakland Museum \\
& Oakland WSOAP \\
San Diego & Upper San Leandro Fltr \\
& San Diego Airport \\
\hline
\end{tabular}


APPENDIX TABLE A.III

Stage-1 Estimation Results

\begin{tabular}{|c|c|c|c|c|}
\hline \multirow[b]{2}{*}{ Variable } & \multicolumn{4}{|c|}{ Dependent variable } \\
\hline & $\ln M P$ & $\ln D$ & In $D P R E C$ & $\ln D T E M P$ \\
\hline \multirow[t]{2}{*}{ Intercept } & -0.32 & 0.02 & -0.11 & 0.0037 \\
\hline & 0.28 & 0.55 & $0.02^{* * *}$ & $0.0021 * * *$ \\
\hline \multirow[t]{2}{*}{ LNP1 $(-1)$} & -0.16 & -0.55 & & \\
\hline & $0.08^{* *}$ & $0.23^{* * *}$ & & \\
\hline \multirow[t]{2}{*}{$\operatorname{LNP} 2(-1)$} & 1.16 & 0.70 & & \\
\hline & $0.11^{* * *}$ & $0.35^{* *}$ & & \\
\hline \multirow{2}{*}{ LNP3(-1) } & -0.2 & -0.25 & & \\
\hline & $0.07^{* * * *}$ & $0.15^{* *}$ & & \\
\hline \multirow[t]{2}{*}{ LNLOT } & -0.04 & -0.01 & & \\
\hline & $0.007^{\text {**** }}$ & $0.008^{*}$ & & \\
\hline \multirow[t]{2}{*}{ LNHH } & 0.18 & -0.04 & & \\
\hline & 0.2 & 0.39 & & \\
\hline \multirow[t]{2}{*}{ LNINC } & 0.05 & -0.002 & & \\
\hline & 0.06 & 0.12 & & \\
\hline \multirow[t]{2}{*}{ BLOCK } & & $0.07^{*}$ & & \\
\hline & & 0.04 & & \\
\hline \multirow{2}{*}{$\ln D(-1)$} & & $0.82^{* *}$ & & \\
\hline & & 0.05 & & \\
\hline \multirow[t]{2}{*}{ SIN1 } & & & 0.01 & -0.0028 \\
\hline & & & 0.02 & 0.0021 \\
\hline \multirow[t]{2}{*}{ SIN2 } & & & 0.07 & -0.004 \\
\hline & & & $0.02 * *$ & $0.002 * *$ \\
\hline \multirow[t]{2}{*}{ SIN3 } & & & -0.08 & 0.0055 \\
\hline & & & $0.02 * * *$ & $0.0021 \% *$ \\
\hline \multirow[t]{2}{*}{ SIN4 } & & & 0.06 & -0.0018 \\
\hline & & & $0.02 * * *$ & 0.002 \\
\hline \multirow[t]{2}{*}{ SIN5 } & & & -0.03 & -0.0049 \\
\hline & & & 0.02 & $0.0021^{* *}$ \\
\hline \multirow[t]{2}{*}{$\operatorname{COS} 1$} & & & -0.17 & -0.0024 \\
\hline & & & $0.02 * * *$ & 0.0022 \\
\hline \multirow[t]{2}{*}{$\operatorname{COS} 2$} & & & -0.09 & 0.0064 \\
\hline & & & $0.02^{* * *}$ & $0.0023^{* * *}$ \\
\hline \multirow[t]{2}{*}{$\cos 3$} & & & -0.08 & 0.0032 \\
\hline & & & $0.03^{* * * *}$ & 0.0022 \\
\hline \multirow[t]{2}{*}{ COS4 } & & & -0.005 & -0.0027 \\
\hline & & & 0.02 & 0.0023 \\
\hline \multirow[t]{2}{*}{ COS5 } & & & -0.16 & 0.0075 \\
\hline & & & $0.02 * * *$ & $0.0022^{* * * * *}$ \\
\hline \multirow[t]{2}{*}{ COS6 } & & & -0.01 & -0.0012 \\
\hline & & & 0.02 & 0.0015 \\
\hline$R^{2}(\mathrm{Adj})$ & 0.91 & 0.85 & 0.14 & 0.04 \\
\hline
\end{tabular}

* Significant at the .10 level.

** Significant at the .05 level.

$* *$ Significant at the .01 level. 
APPENDIX TABLE A.IV

Estimation Results Under Full Climatic Specification

\begin{tabular}{|c|c|c|c|}
\hline Variable & Est coefficient & Variable & Est coefficient \\
\hline Intercept & $\begin{array}{l}2.62 \\
0.15^{* * *}\end{array}$ & $\begin{array}{c}\text { In } P \hat{R E C} \\
0.01\end{array}$ & -0.01 \\
\hline $\ln \hat{\mathrm{MP}}$ & $\begin{array}{l}-0.16 \\
0.03^{* * *}\end{array}$ & $\begin{array}{l}\text { SIN1 } \\
\quad 0.02^{* * *}\end{array}$ & -0.28 \\
\hline $\ln \hat{D}$ & $\begin{array}{l}0.01 \\
0.01\end{array}$ & $\begin{array}{l}\text { SIN2 } \\
0.02\end{array}$ & 0.02 \\
\hline INFO1 & $\begin{array}{l}-0.08 \\
0.02^{* * *} *\end{array}$ & $\begin{array}{l}\text { SIN3 } \\
0.02\end{array}$ & -0.01 \\
\hline REBATE & $\begin{array}{c}-0.003 \\
0.02\end{array}$ & $\begin{array}{c}\text { SIN4 } \\
0.02\end{array}$ & -0.01 \\
\hline RETRO & 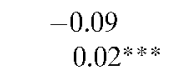 & $\begin{array}{c}\text { SIN5 } \\
0.02\end{array}$ & 0.002 \\
\hline RATION & 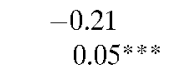 & $\begin{array}{l}\text { COS1 } \\
0.02^{* * * *}\end{array}$ & 0.10 \\
\hline RESTRICT & $\begin{array}{l}-0.34 \\
0.06^{\text {**** }}\end{array}$ & $\begin{array}{r}\operatorname{COS} 2 \\
0.02\end{array}$ & -0.01 \\
\hline COMPLY & $\begin{array}{l}0.003 \\
0.02\end{array}$ & $\begin{array}{r}\cos 3 \\
0.02\end{array}$ & -0.02 \\
\hline LNINC & $\begin{array}{l}0.24 \\
0.10^{* *}\end{array}$ & $\begin{array}{r}\mathrm{COS} 4 \\
0.02\end{array}$ & 0.004 \\
\hline LNLOT & $\begin{array}{l}0.27 \\
0.03^{\text {*水 * }}\end{array}$ & $\begin{array}{r}\text { COS5 } \\
0.02\end{array}$ & -0.01 \\
\hline HIRR & $\begin{array}{l}0.52 \\
0.05^{\text {* * * }}\end{array}$ & $\begin{array}{r}\text { Cos6 } \\
0.01\end{array}$ & 0.01 \\
\hline LIRR & 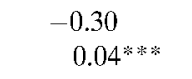 & $\begin{array}{l}\text { RHO } \\
\qquad 0.03^{* * * *}\end{array}$ & 0.58 \\
\hline $\ln T E \hat{E M P}$ & $\begin{array}{l}0.44 \\
0.13^{* * *}\end{array}$ & $R^{2}(\mathrm{Adj})$ & 0.95 \\
\hline
\end{tabular}

* Significant at the .10 level.

** Significant at the .05 level.

$* * *$ Significant at the .01 level.

\section{REFERENCES}

1. D. E. Agthe, B. R. Billings, J. L. Dobra, and K. Raffiee, A simultaneous equation demand model for block rates, Water Resources Res. 22, 1-4 (1986).

2. R. A. Berk, T. F. Cooley, C. J. LaCivita, S. Parker, K. Sredl, and M. Brewer, Reducing consumption in periods of acute scarcity: The case of water, Social Sci. Res. 9, 99-120 (1980).

3. R. B. Billings, Alternative demand model estimators for block rate pricing, Water Resources Bull. 23, 341-345 (1987).

4. T. Chesnutt and C. McSpadden, "A Model-Based Evaluation of Westchester Water Conservation Program," A\&N Technical Services, San Diego (1991).

5. H. E. Doran and J. J. Quilkey, Harmonic analysis of seasonal data: Some important properties, Amer. J. Agricult. Econom. 54, 646-651 (1972).

6. E. J. Hannan, The estimation of seasonal variation, Australian J. Statist. 2, 1-15 (1960).

7. C. W. Howe and F. P. Linaweaver, Jr., The impact of price on residential water demand and its relation to system design and price structure, Water Resources Res. 3, 13-31 (1967).

8. C. V. Jones and J. Morris, Instrumental price estimates of residential water demand, Water Resources Res. 20, 197-202 (1984).

9. R. A. Lyman, Peak and off-peak residential water demand, Water Resources Res. 28, 2159-2167 (1992).

10. J. Moncur, Urban water pricing and drought management, Water Resources Res. 23, 393-398 (1987). 
11. M. L. Nieswiadomy, Estimating urban residential water demand: Effects of price structure, conservation, and public education, Water Resources Res. 28, 609-615 (1992).

12. M. L. Nieswiadomy and D. J. Molina, Urban water demand estimates under increasing block rates, Growth and Change 19, 1-12 (1988).

13. M. L. Nieswiadomy and D. J. Molina, Comparing residential water demand estimates under decreasing and increasing block rates using household demand data, Land Econom. 65, 280-289 (1989).

14. J. A. Nordin, A proposed modification of Taylor's demand analysis: comment, Bell J. Econom. 7, 719-721 (1976).

15. M. H. Protter and C. B. Morrey, "A First Course in Real Analysis," 2nd ed., Springer, New York (1991).

16. M. E. Renwick and S. O. Archibald, Demand side management policies for residential water use: Who bears the conservation burden?, Land Econom. 74, 343-359 (1998).

17. M. E. Renwick, "An Econometric Model of Household Water Demand with Endogenous Technological Change under Demand Side Management Policies," Ph.D. Dissertation, Stanford University (1996).

18. L. D. Taylor, The demand for electricity: A survey, Bell J. Econom. 6, 74-110 (1975).

19. K. F. Wallis, Testing for fourth order autocorrelation in quarterly regression equations, Econometrica 40(5), (1972). 